\title{
Law in the semi-periphery: revisiting an ambitious theory in the light of recent Portuguese socio- legal research
}

\author{
Pierre Guibentif"
}

\begin{abstract}
There is currently no mechanism - no journal, no learned society - somehow integrating Portuguese sociology of law, despite a considerable academic production. In an attempt to appreciate globally and substantially this production, this paper takes as a starting point the theory of semi-periphery formulated by Boaventura de Sousa Santos in the I980s, and revisits the findings of socio-legal research carried out in Portugal over the recent decades in the light of that theory. The conclusion that can be drawn from this exercise is that the theory of semi-periphery - provided it is upgraded in order to better take into account features of recent processes of globalisation - still supplies a valuable framework for the reflection on the social, economic and political conditions that favour uses of the law as a tool for human groupings to govern themselves.
\end{abstract}

\section{Introduction}

For the moment, there is no structure representing socio-legal research in Portugal; neither stable grouping, nor any academic journal specialised in socio-legal issues. ${ }^{\mathrm{I}}$ This means: no source offering to the interested reader easy access to what is going on in this field. Under these circumstances, it seems advisable to open this paper - Part II - with a summary account of the recent development of the social sciences in Portugal. This should enable us to meaningfully locate and characterise the actually rather abundant socio-legal literature produced over the last decades. ${ }^{2}$ It also should allow us to identify, in Part III, a possible integrating topic. Such a topic is supplied by the theory of the semi-periphery formulated in the I 980 os by Boaventura de Sousa Santos. One way of appreciating globally Portuguese socio-legal research is to examine to what extent it confirms this theory. Part IV will discuss empirical findings likely to be related to it. This exercise will lead us, in conclusion, to a very sketchy reformulation of the theory and to proposals for a research agenda derived from this reformulation.

\section{Institutional framework - history and current situation}

Recent Portuguese history is strongly shaped by the transition from an authoritarian regime to democracy in April 1974. Social sciences entered a period of sustained development only after that

* Dinâmia'CET-IUL at ISCTE-IUL University Institute of Lisbon. Email: pierre.guibentif@iscte.pt

I A situation differing in particular from the one prevailing, for example, in France (Israël, 2013), Germany (Machura, 2012, p. 517), Italy, Japan (Murayama, 2013, Introduction), the Netherlands (Hertogh, 2012, p. I40), the United Kingdom or the United States of America. Different also from Brazil, where an association of researchers in sociology of law, created in 2010, has published its own academic journal since 20II (online: 〈http://www.abrasd.com.br/revista.php〉).

2 This literature has already given rise to several review articles (Beleza, I990a; Ferreira and Pedroso, 2000; Cantante, 20I2) which show the relevance of Portuguese scientific production in this domain. 
transition. We shall focus here on sociology. A first research unit in 'social research', the Gabinete de Investigação Social (GIS), was created in I962. Under the directorship of Adérito Sedas Nunes, it launched in 1963 its own journal, Análise Social. ${ }^{3}$ For several years it remained an isolated initiative, and the word 'sociology' was cautiously avoided in its official designation. The first sociology degree was launched soon after the Revolution at the Instituto Superior de Ciências do Trabalho e da Empresa (ISCTE), a university institute newly established in Lisbon, specialising in management and social sciences. In the following years, social sciences were promoted in all other Portuguese universities. Important initiatives were taken at the Coimbra University. Linked to new teaching units, a research centre was created, Centro de Estudos Sociais (CES), headed by Boaventura de Sousa Santos, who also launched in 1978 a journal, the Revista Crítica de Ciências Sociais. The first academic journals to use the word 'sociology' in their title were Sociologia Problemas e Práticas, launched in 1985 by researchers based at the ISCTE, and Sociologia, launched in I99I by António Teixeira Fernandes from the Sociology Institute of the Oporto University. The Portuguese Sociological Association was established in 1985, under the auspices of the International Association of Sociology. Its first conference took place in I988.

The further evolution of sociology - and more generally of social sciences - in Portugal might be interpreted as being, to a significant extent, conditioned by the development of what can be called a new research market. This evolution is linked to Portugal's joining the European Community in I 986 , which triggered a considerable demand for data on the social situation of the country. From then on, numerous research projects were distributed among the existing research units on the basis of competitive calls for proposals, by European as well as by Portuguese governmental agencies.

In the socio-legal field, a special challenge was, in the early I990s, a call for wide-ranging research on litigation and courts in Portugal, issued by the Centro de Estudos Judiciários (CE); centre for the training of magistrates). The proposal of CES in Coimbra was accepted. The research carried out led to the publication of Os Tribunais Nas Sociedades Contemporâneas : O Caso Português (Santos, Marques, Pedroso, and Ferreira, I996), and, at the same time, to the establishment, under the auspices of the Portuguese Ministry of Justice, of a Permanent Observatory for Portuguese Justice, under the directorship of Boaventura de Sousa Santos. This observatory produced an impressive array of research reports - most of them publicly accessible 4 - on topics relevant for judicial policies.

The transformation of Portuguese social research into a competitive market had a strong impact on its daily practice. The sociology of law offers here a revealing example. In 1985 an association for the study of law in society had been created, as an initiative of Boaventura de Sousa Santos. It organised several informal meetings, gathering researchers from different institutions, and published a newsletter from I986 up to I989. The discontinuation of these activities could be related to the increasing workload faced by many of the people involved, as a result of the demands of the research market. After the early I990s, for about twenty years, there were no further meetings which gathered sociologists of the law from the different centres where sociolegal research was being carried out.

A survey of papers published in Portuguese journals of the social sciences ${ }^{5}$ reveals the CES in Coimbra as the most productive of these centres. 'Law in Society' has been one of its main research topics, a priority confirmed by the links between this centre and the Permanent Observatory for Portuguese Justice. This orientation is the direct result of the policy options of its

3 Online: 〈http://analisesocial.ics.ul.pt/〉.

4 See online: 〈http://opj.ces.uc.pt/portugues/apresentacao/>.

5 A permanent survey of this literature is produced by students in the sociology of law at ISCTE-IUL as part of the assignment exercise: short reviews written by them are published online: <http://cadeiras.iscte-iul.pt/SDir/ SDir art.htm >. I am grateful for all the discoveries they shared with me at the occasion of this exercise, which supplied valuable material for the present paper. 
founder, Boaventura de Sousa Santos. In the US, Santos had received a PhD in the sociology of law, based on fieldwork carried out in Brazil on the practices of informal justice in a favela close to Rio de Janeiro (Santos, 1974). When he returned to Portugal in 1974, it was with the aim of developing the sociology of law in this country. ${ }^{6}$

Socio-legal research is also being carried out at ISCTE-IUL in Lisbon (law and the media, law and governance, law and science, prisons, surveillance technologies, lawyers: Caetano, 2003; Dores, 2003; Dores and Preto, 2013; Frois, 20I I; Gonçalves and Guibentif, 2008; Guibentif, Gorjão and Cheta, 2002), at the CICS of Minho University in Braga (new technologies and their impact in the field of law, prisons: Duarte, 2012; Gomes, 2013; Machado, 2007), at Universidade Nova de Lisboa, at the faculty of social sciences and humanities (legal rhetoric, deviant behaviour, legal professions: Borges, 2005; Carvalho, 2010; Chaves, 2010), and at the law faculty (legislation, citizenship, alternative dispute resolution: Hespanha, 2007; Almeida, Caupers and Guibentif, 2014). Research on topics closely related to the socio-legal domain also takes place at ICS (political institutions, corruption, trust in justice: Cabral, 2000; Magalhães, I995; Sousa, 20II, Vala, Ramos and Silva, 2012), and at the university of Évora (theory of society with reference to the law: Rocha-Cunha, 2005).

The most relevant recent development in socio-legal research was the establishment of a new foundation specialising in the promotion of research on Portuguese society, the Fundação Francisco Manuel dos Santos, an entity funded by an economic group operating a big network of supermarkets in Portugal. Under the directorship of António Barreto, this foundation has extensively published on legal issues, among other topics: economic justice, the constitution, legislation (Sousa, 20II; Tavares, Maduro, Garoupa and Magalhães, 20II; Gouveia, Garoupa and Magalhães, 2013).

Even if communication and co-operation between these centres is currently scarce, there is one meeting place that has become more and more important over the last years: the conferences of the Portuguese Sociological Association. Since 2004, these conferences are structured in different thematic areas, one of these areas being 'Law, Crime and Dependency'. At the two last conferences (Oporto 2012 and Évora 20I4), this area attracted a significant number of participants. ${ }^{7}$ It is now about to be transformed as a permanent section of the Association.

One more feature of Portuguese socio-legal scholarship is worth a mention: the strong links between Portuguese research and research carried out in other Portuguese-speaking countries. After his early research in Brazil, Boaventura de Sousa Santos also co-ordinated research on Cabo Verde (Santos, I984), Macau (Santos and Gomes, I998) and Mozambique (Santos, 2003). Other researchers did work on Macau (Hespanha, 2003) and Angola (Guedes, 2003). In recent years, many Brazilian researchers participated in the conferences of the Portuguese Sociological Association and published in Portuguese academic journals.

\section{One possible integrating topic: the theory of the semi-periphery}

In order to identify a topic likely to give a general account of socio-legal research carried out in Portugal, it makes sense to take as a starting point the debates in which Boaventura de Sousa Santos took part, given the central position of this author. Among others, two such debates seem to be particularly relevant.

6 Remember that the Revolution took place a few years after the 'reform movement' that elsewhere gave a new momentum to socio-legal research. For details on this period in the German case, see Machura (20I2, pp. 5I2f.).

7 Thirty-seven papers and four posters presented in 20I2; thirty-four papers and four posters in 20I4: see their references online: 〈http://cadeiras.iscte-iul.pt/SDir/SDir doc APS.htm〉; see also the official website of APS, online: 〈http://www.aps.pt〉. 
The first one is the Portuguese debate on post-modernity, in the late I980s. It started with a seminar organised at the Universidade Nova de Lisboa. Boaventura de Sousa Santos, who had already presented a paper on post-modernity at Amherst College (Santos, I988), was one of the speakers, and defended a thesis that inspired much of the research carried on at the CES in Coimbra in the following years. Portugal, being a 'semi-peripheric' country, did not fully implement the project of modernity, but this was seen as a chance: the country could, on several levels, make the direct transition from a pre-modern to a post-modern stage of development, thereby avoiding the errors of modernity (Santos, I988/I994). ${ }^{8}$ One of the main errors of modernity would be to make too sharp a distinction between common sense and specialised skills, and between different specialised skills, thus reinforcing the power of elites upon the common people. What was at stake from then on was to develop a 'new common sense' (the title of his book published some years later in English: Santos, I995), where politics, law, science and the day-to-day knowledge of the common people have to be combined. This thesis gave rise to substantial reactions, in particular from the part of other Portuguese sociologists. Several papers presented at the second conference of the Portuguese Association of Sociology may be read as responses to this position (Fernandes, I993; Pinto, I993). They argued that adequate distance had to be kept between science and common sense, though they recognised that science, and in particular sociology, needed to become more reflexive, and to pay more attention to the cultural changes shaping the common sense of our time.

The second debate took place in a political setting. In I996, a working group was set up by the government in order to produce a white paper on social security with a view to reforming Portuguese social security legislation. Boaventura de Sousa Santos was appointed a member of this group, having published, in part with other researchers of the CES, papers on social policies (Santos and Hespanha, I987). Some members of this group did defend positions inspired by the doctrine promoted at that time by the World Bank. In opposition to that doctrine, other members, including Boaventura de Sousa Santos, presented their views of social security in a book (Santos et al., I998), giving public visibility to the political debate opposing those who argued for the development of a market for complementary private pension schemes, and those who argued for reinforcing the public pension system. This was an opportunity for Santos to gain publicity for arguments which he took up again on many occasions over the next years: the need for organised local - in this case national - answers to the challenges of globalisation. There is a direct line from this debate on social security in the rggos up to the recent debates on the financial crisis, and on the austerity policies imposed on Portugal by the European Commission, the European Central Bank and the International Monetary Fund. Santos participated in these debates by supporting in 2012 the setting up of a 'Congress of the Alternatives', and by launching, at about the same time, an 'Observatory of Crises and Alternatives'. ${ }^{9}$

These two debates evolved at some distance from the socio-legal domain. However, they have, in Boaventura de Sousa Santos's work, a common origin: his paper on Portugal in the semi-periphery of the world system (Santos, I985/I990), ${ }^{\text {IO }}$ a paper of direct socio-legal relevance. Let us remind

8 In further stages of the 'Law in other contexts' comparative exercise to which the present paper aims at contributing, it would be worth studying the difference between the attitudes towards Western modernity of Santos, in Portugal, and Kawashima, in Japan (Murayama, 2013). Interestingly, radically different approaches, shaped at different historical periods, led to conceptual frameworks comparable in the way they try to better identify the amazing meld of legal and non-legal elements that make the force of Western law.

9 See online: 〈http://www.ces.uc.pt/observatorios/crisalt/〉.

Io First published in 1985 in the journal of ICS, Análise Social, the paper was later included, with some additions, in a collection of papers issued by Boaventura de Sousa Santos in I990, under the heading O Estado e a 
ourselves of its main argument. Portugal is characterised by a disconnection between production (the activity of private and public enterprises) and reproduction (the consumption of goods and services), as well as, on these two levels, between the institutional framework and the current social practices, which means, in particular, a high level of ineffectiveness of Portuguese legislation. The post-modern argument mentioned earlier consists in withdrawing from efforts to reconcile these two levels, in favour of the development of local forms of knowledge and legality. This argument leads Santos to give central relevance to a broad concept of legal pluralism: state law is only one among many forms of legality, and other forms deserve to be better identified by sociologists, and should play a more important social role. On the other hand, the argument for Portugal's strategy on the process of globalisation is based on the assumption that it is still possible, and necessary, to re-establish bridges, on a national level, between common sense and the activity of the state, for example by the means of policies for better access to the law.

Given, on the one hand, the place of Boaventura de Sousa Santos in Portuguese socio-legal studies, and, on the other hand, the relevance of the semi-periphery topos in the debates in which he did participate, in the formulation of his research programme in the sociology of law, and in the accounts he nowadays gives of his research experience in Portugal (Jerónimo and Neves, 20I2, pp. 692, 696), this topos could be an appropriate motive for guiding a general appraisal of what socio-legal scholarship in Portugal has produced over recent years.

This leads to a review method that could be defended in the following terms. We shall take the ideas on law organised by Santos around the topos of semi-periphery as what Merton would have named a middle-range theory (Merton, I968), and check whether this theory is backed by the results of research carried out by other authors, or is likely to provide meaningful interpretations of such results. Taking Merton's lessons seriously, however, this exercise requires us first to 'codify' the theory which we intend to apply here to the discussion of empirical findings presented by Portuguese socio-legal literature. This is also advisable for a historical reason: unlike Santos's arguments on post-modernity, or on Portugal in the globalisation process, the argument on semiperiphery has not given rise to a substantial debate. ${ }^{\text {II }}$

An attempt at codifying Boaventura de Sousa Santos's argument on the semi-periphery for the aims of the present paper implies a precise location of the law in it. As a matter of fact, the two main concepts in Santos (I985/r990) are, as the title shows, not law, but state and society. Indeed law appears only in the second part of the paper, in the discussion of the internal 'disarticulation' of two social spheres: on the one hand, production, in the sense of a world of enterprises producing goods and services, and, on the other hand, reproduction, the world of domestic units where the manpower is reproduced (I985/r990, pp. I26f.). Law appears there as an instrument of the state in its attempts to act on the sphere of both production and reproduction. At this point, Santos gives a broad set of examples of legislation not effectively applied (pp. I37f.), suggesting by the construction of the paper a link between these cases of ineffectiveness and a complex of three

Sociedade em Portugal (1974-I988) (Santos, I990a). It develops an argument presented at about the same time in a first English formulation (Santos, I986), a paper reviewed by Cabral (I987).

I I The paper on Portugal at the semi-periphery of the world system was presented by Boaventura de Sousa Santos at a seminar organised in 1985 by ICS, and it was first published in the journal of ICS - as mentioned supra note Io, a remarkable case of inter-institutional exchange. The invitation came from Manuel Villaverde Cabral, senior researcher at ICS, and critical of Santos's analysis of Portuguese social reality. However, Villaverde Cabral, in his publications of that time, did not elaborate in particular on the topic of the semiperiphery (Cabral, I987). One way of expressing his distance towards Santos was to give emphasis, among his main theoretical references, to Luhmann's systems theory, as a strong alternative to critical social sciences. See Cabral (I999), explicitly opposing critical theory by a reasoning based on Luhmann. Manuel Villaverde Cabral confirms this position - criticising Santos's critical sociology, and qualifying Luhmann's theoretical proposals as offering a highly valuable approach to modern society - in an interview recently published in Portugal: 'Manuel Villaverde Cabral: O encanto da sociologia', Público 2, I9 January 20I4: I6-20. 
other facts: (i) the Portuguese institutional and legal framework follows the 'model currently followed in capitalist countries of the centre' (p. I30); (ii) unlike what he admits has happened in such countries, here it is not the result 'of a slow social process, a process of organic development, of cognitive maturing, of autonomous organization' (p. I32); (iii) there is a discrepancy between the 'legal and institutional' level of the state's activity (the enactment of legislation, and the creation of bodies charged with its implementation) and the 'concrete and effective practice' of state agencies (p. 135). The paper does not elaborate upon the relationship between these three facts. To make this relationship explicit is one of the aims of the following effort at codification.

A first step in this codification is to identify the elements of the social reality necessarily implied in the quoted statements. Boaventura de Sousa Santos approaches here what he names elsewhere as an 'inter-state system' (Santos, I986, p. I93). What are the elements of this reality? First, a plurality of states, and, between these many states, inequalities which are compared with those existing between social classes (p. I9I). Second, as the main conceptual opposition suggests, societies which relate to each of these states, a relationship tackled in a question at the beginning of the paper: 'What are the limits of the state's action, and this means: what are the interfaces of the state's action with societal action?' (Santos, I985/r990, p. I I3) Third, the complex structure of the states, which is due, on the one hand, to the variety of the domains of state activity (p. I4I), and, on the other hand, to the distance crucial for the present discussion - between the 'legal and institutional matrix' and the 'day-to-day social regulation' (p. I35). In the paper, this distance is related to a distinction between an 'official state' and an 'unofficial state' (I985/I990, p. I36; I986, p. I88). Since there is, according to the model here reconstructed, a society outside the state, and in a context where the notions of centre and periphery play an important role, these distinctions suggest the picture of states having a certain extension, with parts at their periphery, in direct contact with society (in the narrow sense of the concept), and other parts central, at some distance from society.

The three elements now identified can be combined into what we could call the theory of the semi-periphery. More precisely, it seems possible to formulate two versions of such a theory, according to the causal nexus hypothetically introduced in the model. And the two versions are to be met in the papers here discussed. They could be merged into a more complex model, but it makes some sense, for the present codifying exercise, to separate them. One version says that the characteristics of a national society - a disjunction between the production sector and the reproduction sector - help the state to cope with an economically critical situation without completely developing mechanisms that exist in other states to address similar economic problems, and this gives the state characteristics that deserve to be qualified as semi-peripheral (characteristics of society $\rightarrow$ semi-peripheral features of the state; in this sense, Santos, I986, p. 192). The other version says that, due to their positions in the interstate system, certain states develop characteristics that are detrimental to their relation to society (semi-peripheral position of the state $\rightarrow$ characteristics of the state $\rightarrow$ state-society relation; in this sense, Santos, I985/r990).

We are now in a position to more precisely locate law in this model of social reality. Law is explicitly mentioned as relating to the centre of the state; hence the phrasing 'legal and institutional matrix'. Here the term 'law' designates only one of the multiple social phenomena Santos wants to take into account within the broad concept of law that he defends. According to his terminology, what is at stake here is, more precisely, 'territorial law', which is the law that corresponds to states as structural contexts of social practice. ${ }^{\text {I2 }}$ So the theory of the semi-periphery addresses in the first place state law. But it also refers to other types of law. Indeed, the notion quoted above of 'day-to-day social regulation' brings in another aspect of legal reality: the

I2 The typology of the different forms of law is most clearly presented in tables that are to be found in Santos (I99ob, p. 33) and (I995, p. 4I7). To compare these two tables allows us to precisely reconstruct different evolutions in Santos's thought throughout the rggos. 
application of legal rules by agencies operating at the periphery of the state, in direct contact with society. The theory of the semi-periphery emphasises the distance between these two forms of law.

More specifically, what does the theory of the semi-periphery, based on the model of social reality reconstructed above, say about the law? On a first level, it repeats the most obvious socio-legal scholarship: there is a gap between law-in-books and law-in-action (Santos, I986, p. I80). ${ }^{\text {I3 }}$ But it adds to these assumptions a set of more specific explanatory hypotheses. It says that in a country like Portugal, it is worth, in the attempt to explain the ineffectiveness of certain legislation, taking into account the semi-peripheral characteristics of the Portuguese state and society. This guides our inquiry to the following phenomena.

First, there is what we could name the structural mechanisms of the neutralisation of the law. If the law is not applied, it is due to characteristics of the state apparatus. This can be derived from the examples introduced by Santos in the points 'Non-application of the law' and 'Selective application of the law' (Santos, I985/1990, pp. I37f.). Agencies required for the implementation of certain laws are not created; governmental decisions are taken in the sense of not applying certain legislation. The structural feature of these situations of the ineffectiveness of the law is rendered by the notion of 'parallel state', the notion of a discrepancy between the 'official state' and the 'non-official state' (Santos, I986, p. I88). The reality on which Santos wants to guide our attention is not a set of occasional cases of non-compliance; it is organised non-compliance: 'In Portugal, the state that produces the formal and official legality is also in a way (through negative policies) the producer of informal, non-official legality' (p. I80).

The theory of the semi-periphery aims at establishing a meaningful link between these cases of organised non-compliance and the features of semi-peripheral countries. According to the paper, the duality of the state is due to the fact that the discrepancies internal to both production and reproduction 'pass through' the state apparatus (Santos, I985/I990, p. I35). The discrepancies, in turn, are discussed as related to the fact that - part of these fragments have been quoted above 'model(s) currently followed in capitalist countries of the centre' (p. 130), unlike what happens in such countries, are not the result, in Portugal, 'of a slow social process, a process of organic development, of cognitive maturing, of autonomous organization' but 'are the result of deep and rapid ruptures' (p. I32).

This tentative codification of the semi-periphery theory leads to a set of - admittedly very broadly formulated - hypotheses on law in semi-peripheral countries: (I) international influence emanating from other states, mediated by international organisations, circulating within the 'inter-state system' - plays an important role in the production of law; (2) more specifically, this influence can be the result of pressures from the part of certain central countries; (3) domestic social forces are weakly organised and play a minor role in the production of law; (4) mediations between the sphere of law-making and situations where legislation is applied are scarce; in particular there are (4a) gaps within the state apparatus itself ('parallel state') and (4b) within the legal system - Santos admits, at least in later writings, that law could be a means of communication between state and society, ${ }^{\mathrm{I}} \mathrm{a}$ and (4C) information for non-specialists on legal issues, notably by the media, is inadequate; ${ }^{\mathrm{I5}}$ (5) the national legal system is more directly shaped (5a) by state influence and ( $5 \mathrm{~b}$ ) by international influence than by demands on the part of society,

I3 For a summary overview on this topic in socio-legal studies, see Hertogh (20I2, pp. I46f.).

I4 See the following statement: 'Official law is of central relevance: it is the main means of expression (articulador), the main language through which the state addresses civil society' (Santos, in Miranda, Marteau, Costa, Rocha and Motta, I996, p. I37).

I5 'It is also important to strengthen (in Portugal) the Habermasian public sphere' (Jerónimo and Neves, 20I2, p. 7OI). 
or by interaction between legal professions; and (6) a generally high level of non-compliance with legislation is likely to relate to facts pointed by the other hypotheses (I) to (5).

\section{Does recent socio-legal research confirm the 'semi-peripheral' features of law in Portugal?}

What will be undertaken in this section is an examination of the findings reported by Portuguese socio-legal literature to see if they confirm these hypotheses. If this junction is not confirmed, or just to a limited extent, we will have to recognise that the topos of the semi-periphery does not accurately characterise Portuguese legal reality, or at least not anymore, and we will have to look for another integrating topic, if there is one. If it is to some extent confirmed, our conclusion should not simply be: yes, Portugal is a semi-peripheral country, but rather: yes, the topos of the semi-periphery points to issues that still deserve to be discussed in socio-legal studies. The Portuguese case may provide material for a more precise and in-depth discussion of these issues, even if such a discussion, obviously, should not limit itself to the case of this country.

Findings which could not be meaningfully qualified with this set of hypotheses should not be excluded from the scope of the present paper. They could reveal the limits of the theory of the semi-periphery. Actually, its formulation dates back to the I980s and, obviously, many changes have taken place in the meantime. More recent findings could oblige us to update it.

Since this will oblige us to fragment research results according to their relevance regarding the different aspects of the theory here reconstructed, it seems advisable to shortly introduce in more general terms the contents of some of the most important Portuguese socio-legal research, in order to enable the reader to appreciate in more general terms the accuracy of our general appraisal.

As far as works with some public impact are concerned, we first look at the research on Portuguese courts carried out by the team of Boaventura de Sousa Santos in the Ig9os (Santos et al., I996). It was followed by several reports and books from the Permanent Observatory for Portuguese Justice (among others: Gomes, 2003, Pedroso, Trincão and Dias, 2003). Two other research projects are worth a mention. One is work on the role of the courts under Salazar's government (Rosas, Pimentel, Madeira, Farinha and Rezola, 2009). It is based on an extensive analysis of state archives; it gives an account of the role of the courts created by the authoritarian regime that ruled Portugal until I974, and tries to reconstruct how the magistrates managed to maintain their social position during the course of the Revolution. The other is research on economic justice, carried out under the auspices of the Fundação Francisco Manuel dos Santos (Gouveia et al., 2013), based on a survey, visits to foreign courts, and in-depth interviews of representatives of the different categories of actor involved. It scrutinises the effective functioning of civil courts in Portugal and formulates a globally negative assessment of the judicial system from the part of Portuguese entrepreneurs. It derives from this assessment a broad set of proposals for the reform of the Portuguese Code of Civil Procedure.

A more detailed picture of socio-legal research is supplied by the list of $\mathrm{PhD}$ dissertations defended over the last decades. Pioneer works were the dissertations of António Manuel Hespanha (I986a) on the structure of the Portuguese state in the seventeenth century - according to a sociologically inspired approach - and of Teresa Beleza (I990b) on the image of women in the Portuguese Criminal Code. More recent references touching the socio-legal field are the dissertations of Cristina Leston-Bandeira (2002) on recent changes in the role of the Portuguese parliament, addressing among other topics the conditions of law-making in Portugal; Manuela Ivone Cunha (2002) on a prison for women and on the way the network of connections between what happens in that prison and outside it causes the social exclusion not only of the inmates, but also of the community to which they belong; António Casimiro Ferreira (2005) on the 
treatment of individual and collective labour conflicts in Portugal, emphasising the lack of nonjudicial mechanisms and the gap between the conflicts subject to judicial treatment and those effectively occurring at the workplace; Helena Machado (2007) on the handling by the Portuguese justice system of paternity research procedures, and on the way these procedures reinforce social norms on the sexual behaviour of women; João Pedroso (20II) on the effectiveness of the right to have access to law in family issues; Madalena Duarte (20II) on the social movements active in the field of environmental law; Susana Santos (2012) on the law-making process which led to the regulation of private radio stations in the period of normalisation between the Revolution and the country's joining the EC; Vera Duarte (20I2) on female delinquency; Patrícia Branco (2013) on the architecture of the courts as revealing the changing status of courts as part of the state's apparatus, and of the relationship between courts and society; Sílvia Gomes (2013), comparing deviant behaviour across different immigrant communities; and João Paulo Dias (2014) on the role of Portuguese public prosecutors, in particular in helping ordinary people to access the courts.

The following survey - structured according to the different hypotheses which form what we called here the theory of the semi-periphery - is based on an analysis of these publications, as well as of other socio-legal papers recently published in the main Portuguese academic journals in sociology and in law.

\subsection{International influence on the production of law}

International influence on the production of law is revealed by three different types of reference. First, several papers refer to the impact of models from outside Portugal on Portuguese public policies and law-making. Short references are made concerning the regulation of prisons (Cunha, 2002, p. 307), the domain of mediation in family issues (Aráujo, Rodrigues, Fernandes and Ribeiro, 20II, p. 304), the regulation of schools, said to be inspired by the recommendations of the OECD (Gomes, 2002, p. 65), public-private partnerships, where the example of the UK is mentioned (Firmino, 20I I, p. 403). In more general terms, Machado (2007, pp. 3I, 224, 233) focuses on the way Portuguese authors of legislative drafts tend to imitate foreign models. A somewhat more detailed discussion is to be found in particular in the following papers. An analysis of the constitutional process of $1975-76$ shows how important, in the discussion of the new Portuguese Constitution, were the references to international legal instruments and to the constitutions of other countries (Vieira and Silva, 20I0, pp. 9of.). The legislation on the Portuguese Supreme Council of the Judiciary is said to be inspired in particular by the Italian example (Magalhães, I995, pp. 70, 78). In a paper on a recent reform of the Portuguese penal code in the matter of abortion, the reform process is analysed as having been favoured by the fact that foreign media did cover trials in Portugal against women who had aborted, based on the previous legislation (Monteiro, 20I2, pp. 59I, 60I). In a paper on the introduction in Portugal of new DNA technologies in the field of judicial investigation, problems in the use of these technologies are related to the fact that they were transplanted from countries with a judicial organisation different from Portugal (Machado and Costa, 20I2, p. 68).

Second, some papers mention the involvement of entities from outside Portugal in the processes of reform. Ferreira (2005, pp. I44f.) describes the role of the ILO in the reforms of the labour market in the late I970s; Duarte (20I I, pp. I05f.) the role of the EU in the development of legislation in the field of environment protection. A study on the organisation of the courts in Portugal is introduced as having been positively valued by the Council of Europe (Bilhim, 2008). In this case, however, we should also remember that this report is said not to have been considered by the Portuguese government in later reform efforts. This is a case in which limits to influences from outside were experienced.

Third, there are publications aiming at leading to political recommendations, which give an important place in their research design to the study of other countries, presented as examples of 
good practice to be taken into account in the reform processes currently going on in Portugal: Irish and German courts in a study of the practice of Portuguese courts in economic matters (Gouveia et al., 20I3, pp. I7If.); the Netherlands, Sweden, Switzerland and the UK, in a study on the quality of legislation (Almeida et al., 20I4).

Another way of referring to the international context are mentions of the position of Portugal in it. At several places, quotations of people interviewed reveal a negative assessment of this position: 'We have to deal with the dimension of our country' [addressing the financial means available; Machado, 2007, p. I87]; 'Here we are not in (... [mention of another country, supposed to comply with higher standards])! (Silva and Machado, 2010, p. 85); 'In those countries, they already have [such a legal mechanism]!' (Gouveia et al., 2013, p. 76). 'There are civilized countries where [such a mechanism] exists' (Gouveia et al., 20I3, p. I20). However, the opposite attitude is also to be found. The broad range of competences of public prosecutors in Portugal is said to attract the attention of foreign specialists, who defend the introduction of a similar system in other countries (Dias, 20I2, p. I96).

\subsection{Pressures on the part of other countries}

On this point it is more difficult to find correspondences between recent socio-legal research and the theory of the semi-periphery as formulated by Santos in the I 980 os. References to pressures on the part of other countries on law-making processes in Portugal are almost absent. One case, dating back to the I96os, is a social security convention signed between Portugal and Germany, which strongly differs from the conventions between Portugal and other European countries. While other conventions simply reproduce the rules of the European regulations in force at that time (Regulation nr. 3), adapting them to the bilateral relations at stake, the text of the convention with Germany is completely new, which is most probably due to specific requirements on the part of Germany (Guibentif, I997, p. I22). In more recent literature, the discussion of the conditions under which financial help was granted to Portugal in order for the country to meet its commitments on the international financial markets points to the role of European and international entities (Ferreira, 20I I, pp. I25f.). These entities did notably include the reform of the justice system on the agenda of the measures to be taken as a counterpart for the support granted.

\subsection{Domestic social forces are weakly organised and playing a minor role in the production of law}

The absence of strong social actors in Portuguese civil society is mentioned several times in the publications of the CES in Coimbra (Santos et al., I996, p. 699; Ferreira, 2005, pp. 203-204). The absence of pressure on the courts on the part of Portuguese society is related to its 'self-solving' feature; to the reported preference of people interviewed for non-official conflict-solving mechanisms (sociedade auto-compositiva; Santos et al., I996, p. 683). Even organised social actors such as trade unions or NGOs operating in the field of the environment do not seem to make intensive use of the legal mechanisms supposed to facilitate their intervention (Ferreira, 2005, pp. 4I If.; Duarte, 20II, p. I85).

Important initiatives in the field of family law are said to be the result of governmental action, and not of direct pressures on the part of civil society (Pedroso, Casaleiro and Branco, 20II, p. 235). A similar statement was made concerning the recent decriminalisation of abortion in Portugal, analysed mainly as an initiative of the socialist party in government at that time (Monteiro, 20I2, p. 598), while feminist movements are qualified as 'fragile' (p. 593).

On the other hand, the fact that certain reforms, which took place in other countries, were not undertaken in Portugal is related to the absence of corresponding pressures on the part of organised social actors interested in such reform (Almeida et al., 20I4, for reforms in the field of the quality of legislation). 
A complementary line of analysis is suggested by Palacios Cerezales (2003, pp. II52f.). Violent actions undertaken locally by the population in 1975 are interpreted as a result of the temporary inconsistency of the state's action: at that moment the central government was temporarily under the strong influence of the communist party, while many governmental agencies and local governments were not ready to follow this orientation. In the light of this episode, the absence of social movements in other periods could be interpreted as a sign of conformity towards governmental rule (conformity also pointed out by Cabral, 2000, p. I09).

\subsection{Insufficient mediation between legislation and legal practice}

Much research highlight the fact that people involved in the processes of law-making or of legal reform lack sufficient knowledge on what happens at the level of the daily application of the law. Statistical data should be used more frequently (Garcia, Garoupa and Vilaça, 2008, p. I04). Even if it has been improved over the years (Leston-Bandeira, 2002, p. I45), information supplied to the parliament is still poor: evaluation ex ante of the impact of legislation under debate is not systematically provided (Almeida et al., 20I4). In contrast, certain practices take place over years without any legal framework (Firmino, 20II, p. 403, on private-public partnerships).

The two main causes of this distance between legislation and legal practice are gaps within the state apparatus and gaps within the legal system, which will be discussed in the next two sections. One problem that does not belong to either of these two categories is reported in research on the decriminalisation of abortion. An Advisory Council created to support women and to gather information about problems they met at home and at their workplace - the Comissão para a Cidadania e Igualdade de Género - plays only a marginal role in this law-making process, probably due to conservative attitudes on the part of its members. Here the influence of the Church (also highlighted by Machado, 2007, p. 24) seems to have prevented the Council from playing its political role of mediating between problems experienced on the ground and public discussion of the new legislation (Monteiro, 2012, pp. 599f.).

\subsection{Gaps within the state apparatus}

Socio-legal research in Portugal frequently mentions gaps between different state agencies. The distance between social security and the health services has hampered the implementation of European social security rules in Portugal (Guibentif, I997, pp. 27 If.). The evaluation of the courts' performance is made difficult by the fact that the judicial territorial division does not correspond to the administrative division (Garcia et al., 2008, p. 47). Courts do not use the address lists of citizens produced by the service which issues identification cards (Gouveia et al., 20I3, p. 5I). Interviews with judges reveal a negative opinion concerning social security services (Pedroso, Casaleiro and Branco, 20II, p. 559). Local authorities have to deal with the segmentation of the Portuguese central administration (Ruivo, 2000, pp. 2I5f.).

\subsection{Gaps within the legal system}

Here, two types of gap deserve to be discussed. On the one hand, gaps within the legal discourse. On the other hand, problems in the relationship between the legal professions.

Machado (2007, pp. 29, I94, 2 I5) points to the gap between legislation - which may be apparently progressive - and decisions taken by the courts - which may be strongly conservative. This gap has to be related to Portugal's recent history. The political conditions under which the Portuguese Constitution was debated in $1975-76$ - it was necessary both to clearly differentiate the new political regime from the authoritarian regime which had ended with the 1974 Revolution, and to maintain a minimum level of consensus between moderate political parties in order to resist more radical political forces - could explain why this Constitution includes a very generous catalogue of individual fundamental rights (Vieira and Silva, 2010). Too generous, in the view of certain 
jurists, to offer appropriate foundations for the Portuguese legal system as a whole (Tavares et al., 20II).

As far as the relations between the legal professions are concerned, the research on economic courts reveals some 'discomfort', illustrated by a number of answers collected in interviews and focus groups (Gouveia et al., 20I3, pp. 4I, 62, 64, 70). A judge specialising in labour law regrets the absence of meetings gathering magistrates and lawyers in this field, adding 'I know in [mentions another European country] there are such meetings' (Ferreira, 2005, p. 242). The research team of Boaventura de Sousa Santos refers to the lack of communication between the two councils supervising the activities of judges, on the one hand, and public prosecutors, on the other (Santos et al., I996, p. 698). The relationship between lawyers and public prosecutors is conditioned by the fact that public prosecutors have broad functions in providing legal information and in the fields of family law, children's rights and the defence of employees, which leads to tensions between these two professional groups (Ferreira, 2005, p. 459; Pedroso, 20II, pp. 563f.).

The tensions between magistrates and lawyers have to be seen against their historical background. While judges were seen as having contributed to the tight social control set up by the authoritarian Salazarist regime, lawyers stress their contribution to the resistance against it (Chaves, 2010, p. I63; Magalhães, I995, p. 68). ${ }^{16}$ The relationship between judges and public prosecutors also deserves to be analysed, taking into account the different consequences the 1974 Revolution had on the two professions: no fundamental change for the judges, while public prosecutors did participate actively in the discussion of the new institutions, and had their mission and careers newly defined by the I976 Constitution (Magalhães, I995, p. 79). Tensions between judges and public prosecutors are reported in relation to the division of labour between the two professions in criminal issues (Dias, 2014, p. 58).

The recent creation of a system of justices of the peace gave rise to one more distinction within Portuguese legal culture (Guibentif, 2007; Chumbinho, 2007).

These gaps and tensions even have a cognitive impact. Garcia et al. (2008, p. I02) notice how fragmentary all analyses of the Portuguese justice system are, due to the lack of communication between the different actors involved. In a certain way, Chaves (2010) confirms this lack of communication. It was possible to write an entire book on young lawyers without mentioning at any point the other legal professions. ${ }^{17}$ As a matter of fact, fragmentation is also a feature of the socio-legal literature in Portugal (Garcia et al., 2008, p. I0I).

\subsection{Insufficient information for non-specialists; media coverage}

Concerning the information available to non-specialists about legal issues, we find the following statement of a judge: 'We judges were not able to organize ourselves in order to properly communicate with the community' (Gouveia et al., 2013, p. 28). The language used in the courts' decisions is said to be too technical (p. 89).

Media coverage is discussed in a paper on the Constitutional Court: the media would establish too narrow a link between judges and the political parties (Magalhães and Araújo, I998, p. 8). Another paper refers to media information on the uses of new technologies by the Portuguese authorities. The construction of the public perception of these uses is conditioned by the fact that the Portuguese media give strong visibility to foreign judicial systems (Machado and Costa, 20I2, p. 80). Another problem, not particular to Portugal, is the relevance given to exceptional cases (Machado and Santos, 20II, pp. I58f.).

I6 On the attitude of judges under the Salazarist regime, see also Rosas et al. (2009, pp. I32, I43, I70); on the role of the lawyers, and on the position of the Portuguese Bar Association (pp. 62, I48, I70, I96, 269).

I7 One exception, Chaves (20I0, p. I60), where a short mention of the 'remaining legal professions' is to be found. 
In relation to these findings, it is worth remembering the general statement of Cabral (2000, p. IIO) of a 'communicational deficit' in the relationship, in this case, between the government and the population in Portugal.

\subsection{Legal system under strong governmental influence}

Research on labour justice makes numerous references to the 'centrality of the state' (Ferreira, 2005, pp. 47, I34, I7I). This notion may correspond to two different types of governmental intervention. On the one hand, there are initiatives of the government at the level of legislation. Available research offers examples in domains such as family law (Pedroso et al., 20I I, p. 235) or non-judicial dispute resolution (Garcia et al., 2008, p. I04). Research on the production of legislation on private radio transmitters shows how the government could control the procedure following its own agenda, ignoring the demands of the interested actors and beyond the control of parliament (Santos, 20I2).

More important than individual initiatives in specific domains is the generally dominant role of the government in matters of legislation (Leston-Bandeira, 2002, p. I2 I; Almeida et al., 20I4). This dominant role of the government in the domain of law-making might be seen as a hangover from the former regime. This is one point on which similarities exist between the actual democratic Constitution and the I933 Constitution drafted under Salazar's guidelines (Vieira and Silva, 20Io, p. 92).

On the other hand, there are mechanisms of governmental control of the courts' activity. A very detailed Code of Civil Procedure is interpreted as revealing a lack of trust on the part of the government towards magistrates and lawyers (Gouveia et al., 20I3, pp. 28, 4I, 80). The important role of the courts' secretaries in the management of cases is also highlighted (Garcia et al. 2008, p. 32). Even if there are no direct connections between these two institutional mechanisms, it makes sense to remember here that, during the time of the authoritarian regime, courts competent for political issues did function under the direct control of the political police (Rosas et al., 2009, pp. I32f., I40f., I 5 If., I83, I88, I95).

More generally, the former regime did make intensive use of legislation as a means of government, which has been considered a distinctive feature of Salazar's 'constitutionalised dictatorship' (Rosas et al., 2009, p. 28; Magalhães, I995, p. 55).

On this point, we cannot ignore the strong defence by Portuguese magistrates of their institutional autonomy (Magalhães, I995). Santos et al. (1996, p. 699), however, suggest that, in the absence of strong demands for such independence on the part of civil society, this defence could evolve to a corporatist strategy. Recent evolution shows increasing efforts on the part of the Portuguese government to strengthen the accountability of magistrates (Dias, 2004, pp. I I5, I40).

\subsection{National legal culture strongly influenced by international legal culture}

What is at stake here are influences on the legal reality in Portugal resulting not from political or administrative processes linked to Portugal's participation as a state to initiatives associating different states, but from forms of co-operation between legal professionals in Portugal and their colleagues from other countries.

In the case of lawyers, we have to remember the contacts established, in the I96os, between Portuguese lawyers and international non-governmental organisations promoting human rights (Rosas et al., 2009, p. I47). In a completely different context, recent changes in the practice of advocacy in Portugal are linked to the establishment, in this country, of subsidiaries of big American or British law firms (Chaves, 2010, pp. I33, I43).

João Paulo Dias, in his research on Portuguese public prosecutors, highlights the relevance of the links established by these professionals with their colleagues in other countries, as well as in international organisations (Dias, 20I2, pp. I89f.). However, this research shows influences in both 
senses. The specific features of the public prosecutor in Portugal's judicial system - a particularly broad range of competences - attract the attention of foreign observers.

Within the Portuguese administration, jurists specialising in social issues did over the years cooperate with their colleagues in other countries. This participation in an 'epistemic community' inspired their efforts, in the early I960s, to promote the development of a modern social security system under the corporatist regime of Salazar (Guibentif, I997, pp. 28f.; Vieira and Silva, 20Io, p. I04).

In more general terms, the use of foreign references - in particular German references - by Portuguese jurists for strengthening their social prestige as experts in law is pointed out by António Manuel Hespanha (I986b, p. 316).

\subsection{Generally high level of non-compliance}

The gap between the law in books and the law in action is a well-known socio-legal topic and certainly not a specifically Portuguese feature. However, it could be worth comparing more precisely - an exercise which would require a comparative effort far more demanding than the present survey of Portuguese literature - general levels of the effectiveness of the law in different countries, and the relevance given to the topic of ineffectiveness of the law in these different countries. The fact which cannot be ignored here is that the ineffectiveness of the law is a major issue in Portuguese socio-legal literature.

Ineffectiveness in general terms is a fact accepted by the population: people would accept the existence of a 'parallel state' (discrepancy between the legal framework and administrative practice) as normal (Santos et al., I996, p. 695). This attitude could be related to the comparatively low level of trust in public institutions and in the legal system on the part of the Portuguese people (Vala, Ramos and Silva, 20I2).

António Casimiro Ferreira insists on the general ineffectiveness of labour law at several occasions in his work on labour justice (Ferreira, 2005, pp. I35f., I66f., 204, 309, 405, 467). On the gap between the law in books and the law in action in matters of abortion, see Monteiro (2012, p. 59I). On the ineffectiveness of constitutional rules prohibiting discrimination on the ground of sexual preferences, see Santos, Santos, Duarte and Lima (2009b).

João Bilhim puts forward a quantitative measure of the effectiveness of courts' decisions (item named 'Impact [of the decisions] on society'): I.57 on a scale of 5 points (Bilhim, 2008, p. 534).

Apart from such general statements, ineffectiveness is explained, in much research, by more specific causes. Inefficiency in the use of DNA identification technologies by Portuguese authorities is related to the late setting up of the necessary DNA database, compared with countries where this technology has had more time to develop (Machado and Costa, 2012, p. 68). Difficulties the courts have in meeting the demands of the economy are related to an inappropriate territorial division of the Portuguese judicial map (Garcia et al., 2008, p. 42; Gouveia et al., 20I3, p. 22), or to the rules which limit which new facts can be taken into account in the course of a procedure (Gouveia et al., 2013, p. 40). Statements gathered by Gouveia et al. (2013, p. I28) reveal a negative assessment of arbitration procedures run by Portuguese arbitration centres, due to the lack of autonomy of the arbitrators.

\subsection{Findings that do not fit the theory of the semi-periphery}

Two kinds of finding have to be discussed here. On the one hand, those which open discussions with no direct connection to the topic of the semi-periphery; on the other hand, those which can be related to it, but requiring additions to the model discussed on the basis of Santos's papers from the r98os.

Several papers address the discrimination suffered by women (Ferreira, 2005, pp. 420f.), or male domination of women in Portugal (Beleza, I99ob; Machado, 2007). Related to this topic are several 
papers on domestic violence (Silva, I991; Almeida, André and Almeida I999; Lourenço and Carvalho, 200I) ${ }^{\mathrm{I} 8}$ and on the trafficking of women (Santos et al., 2009a).

One topic formally connected with the topic of the semi-periphery is the difference between centres and peripheries in Portugal itself. Delays in the handling of judicial cases are said to be particularly severe in Lisbon and Oporto compared with other regions of the country (Garcia et al., 2008, pp. 50, 94, I03). Such territorial differences are also mentioned in Santos et al. (I996, p. 69I). Certain new technologies (in-vitro fertilisation) are less accessible in places far from the main urban centres (Silva and Machado, 20I0, p. 88).

Among socio-legally relevant topics tackled by several papers, we have mechanisms of alternative dispute resolution (Frade, 2003; Agra and Castro, 2005; Chumbinho, 2007), legal pluralism (Nolasco, 200I; Araújo, 2008), and violence (Palacios Cerezales, 2003; Dores, 2009, pp. 83f, r83f.).

One additional chapter in Portuguese socio-legal studies could be mentioned here: 'the periphery of the semi-periphery'. Several papers address marginal populations and their own norms, and the policies of social control addressing them (Chaves, 2000; Silva, 2007; Tinoco, 2007; Carvalho, 2010; Duarte, 2012; Gomes, 2013). Connected to this category of papers, much research addresses prisons (Cunha, 2002; Dores and Preto, 2013). ${ }^{19}$ Interestingly, Manuela Ivone Cunha uses the theory of the semi-periphery, and the notion of a 'welfare society' related to it, to explain special features of drug-trafficking networks in Portugal, where participants are to some extent socially integrated (Cunha, 2002, p. 3I2).

The topics listed up to now depart from the 'semi-periphery' topos by their empirical object. Some papers deserve a mention here because they explicitly make use of an interpretive framework different from the theory of the semi-periphery: the hypothesis according to which law contributes to the enforcement of the norms of dominant social groups, notably in matters of sexuality (Almeida, 2006; Machado, 2007, p. I22; Silva, 2007), sometimes recognising, however, that these norms may change over time (Pedroso et al., 20I I, p. 220).

Another set of topics could be connected to the theory of the semi-periphery, provided it is revised on certain points. This is most obviously the case for references to non-governmental players in the current globalisation process. The theory of the semi-periphery, as formulated in the r 980 s, still focuses on what Santos names the 'inter-state system'. This concept centres our attention exclusively on states as players on the global field. Recent research shows that the global processes impacting on Portugal also involve non-governmental players: consultancy firms (Firmino, 20II), multinational law firms (Chaves, 20I0, p. I49), and the European Foundation for Quality Management (Garcia et al., 2008, p. 28; Bilhim, 2008, p. 534). Reports from the Hay Consulting Group and from Anderson Consulting on aspects of the Portuguese judicial system are referred to in a discussion of current attempts to reform this system (Garcia et al., 2008, pp. 21, 27). International courts also now play a more relevant role (Santos, Santos, Duarte and Lima, 2009b). New technologies change the conditions of the transnational relationship, give new relevance to certain players, and generate new dynamics. This is the case in particular in the domain of biomedicine and medical technologies (Cascais, 2006, pp. Iorff.; Silva and Machado, 2010, p. 90). Among the new players, we find large business enterprises, which are mentioned in Santos et al. (1996) as strategically using the Portuguese judicial system, or by Chaves (2010, pp. 158, 253, 289), as requiring a certain type of lawyer and of law firm. ${ }^{20}$ Santos (2012) shows the weight of multinational media groups in the reform of radio regulation in Portugal. Trends toward the

I8 Several papers on this topic were presented at the recent meetings of the Portuguese Sociological Association.

I9 At both recent meetings of the Portuguese Sociological Association, workshops on prisons, illegal behaviour and social control had to be organised, given the number of paper applications received on these topics.

20 These trends are comparable to those observed in Denmark by Hammerslev and Rask Madsen (20I4; section 3.I). 
managerialisation of the courts (Dias, 20I2, p. 439) could be interpreted as attempting to meet the demands of these clients of the legal system.

\section{Conclusion}

Even if recent socio-legal research also deals with rather different topics, many findings do fit the elements of what can be named the theory of the semi-periphery put forward in the I 980 os by Boaventura de Sousa Santos. One could hardly argue that they confirm this theory, but they certainly justify further work on it.

A first part of this further work is to revisit the theory itself, taking advantage of the findings gathered in the meantime, here briefly introduced. Its scope, as we could see, should be broadened. The issue now is not so much the position of Portugal in an 'inter-state system', but its position in the process of globalisation. ${ }^{21}$ The related socio-legal question is the impact, not only of the semi-peripheral position of Portugal, but of globalisation, on the relationship between social action and the law in Portugal. A more demanding task is to consolidate the theory, by proposing a more detailed discussion of its different elements and of the relations between them. And this discussion should be conducted with a view to the construction of more precise indicators, likely to orient future research, not only in Portugal, but also on a comparative basis. One problem on this point is that, at several locations of the conceptual scheme, we have to deal with social forces, a reality rather difficult to observe and to measure (Dores, 2009).

The main question in these future theoretical and empirical efforts could be, using again Boaventura de Sousa Santos's words (Santos, 2002): How can law play an emancipatory role nowadays? In some places and at some moments, a combination of state and law was collectively experienced as a means of autonomous human action, i.e. action that itself defines its own rule. In this disenchanted advanced modernity, we learned that this experience did not last, if it ever really happened. And we try, notably by the means of the social sciences, to understand why, sometimes with the hope of finding ways to bring our imperfect institutions closer to this historical ideal. The discussion of the theory of the semi-periphery contributes to these efforts. It draws our attention to interferences from outside the circular processes by which concrete human groupings seek to integrate and organise, but also to liberate their activities. States, once experienced, at least by certain nations, as an appropriate institutionalising tool for a people, are increasingly conditioned by their position in networks of global players. Law and the legal professions, once experienced, at least by certain social categories, as helpful for insightful dealings with the rules of the community, are increasingly conditioned by concepts and rules shaped transnationally. And states - or most of them - as well as the law, ceased to form the centre of the global world.

States and the law are evolving, on a global level, in a sense that increasingly conditions their potential as tools of self-government. Some communities or people may imagine that the impact of these global evolutions on their life, and especially on their relationship to their law, is marginal. In Portugal, we - as researchers as well as citizens - cannot ignore them and are, therefore, strongly interested in promoting their international discussion.

\section{References}

AGRA, Cândido and CASTRO, Josefina (2005) 'Mediação e Justiça Restaurativa. Esquema para uma Lógica de Conhecimento e de Experimentação', Revista da Faculdade de Direito da Universidade do Porto 2: 95-II 2 .

2 I Boaventura de Sousa Santos recognised this fact by redefining the agenda of CES, focusing since 2000 on globalisation and the position of Portugal in this process (Santos, 200I). 
almeida, Ana Nunes de, André, Isabel Margarida and Almeida, Helena Nunes de (I999) 'Sombras e Marcas: os maus tratos às crianças na família', Análise Social 34: 9I-I 2 I.

almeida, Marta Tavares de, Caupers, João and guibentif, Pierre (20I4) Feitura das Leis. Portugal e a Europa. Lisbon: Fundação Francisco Manuel dos Santos.

almeida, Miguel Vale de (2006) 'O Casamento entre Pessoas do Mesmo Sexo. Sobre "Gente Remotas e

Estranhas” Numa Sociedade Decente’, Revista Crítica de Ciências Sociais 76: 17-31.

aráujo, Emília, rodrigues, Carmen, fernandes, Helena, and Ribeiro, Maria Saldanha (20I I) 'Porque o tempo conta: elementos para uma abordagem sociológica da mediação familiar’, Análise Social 46: $283-308$.

ARAújo, Sara (2008) 'Pluralismo jurídico em África: ficção ou realidade?', Revista Crítica de Ciências Sociais 83: I2 I-I40.

BelezA, Teresa Pizarro (I990a) 'Sociology of Law in Portugal', In V. Ferrari (ed.), Developing Sociology of Law. A World-Wide Documentary Enquiry. Milano: Giuffré, 66 I-685; also published in Portuguese: 'Sociologia do Direito em Portugal', Vértice February r989 (II Série, I I: 49-60).

Beleza, Teresa Pizarro (I99ob) Mulheres, Direito, Crime ou a Perplexidade de Cassandra. PhD dissertation, University of Lisbon.

BILHIM, João (2008) 'A construção da função qualidade nos tribunais portugueses: uma abordagem à luz da teoria institucional', Scientia Jurídica 315: 517-540.

BORGES, Hermenegildo F. (2005) Vida, Razão e Justiça - Racionalidade argumentativa na motivação judiciária. Coimbra: Edições Minerva.

BRANCO, Patrícia (2013) Os Tribunais como espaços de reconhecimento, de funcionalidade e de acesso à justiça$O$ estudo de caso dos Tribunais de Familia e Menores em Portugal. Unpublished PhD dissertation, University of Coimbra.

CABRAL, Manuel Villaverde (I987) 'Portugal Since the Revolution - Review Article', Luso-Brazilian Review 24: 79-86.

CABral, Manuel Villaverde (I999) 'Teoria crítica and informationcritique', Revista Crítica de Ciências Sociais 54: 3I-37.

CABral, Manuel Villaverde (2000) 'O exercício da cidadania em Portugal', Análise Social 35: 85-I I4. CAETANo, António (ed.) (2003) Inquérito aos advogados portugueses - Uma profissão em mudança. Special issue of Revista da Ordem dos Advogados. Lisbon, December 2003.

CAntante, Frederico (2012) O direito no campo da investigação sociológica em Portugal: tendências, tematizações e protagonistas (CIES e-working paper no. I29/20I2). Lisbon: CIES.

Carvalho, Maria João Leote (2010) Do Outro Lado da Cidade. Crianças, socialização e delinquência em bairros de realojamento. Unpublished PhD dissertation, University of Lisbon.

CASCAIS, António Fernando (2006) 'A experimentação humana e a crise da auto-regulação da biomedecina', Análise Social 41: Ior I-1032.

CHAves, Miguel (2000) 'Dar à fuga: sujeito e comunidade num contexto de narco-tráfico', Análise Social 34: 893-932.

Chaves, Miguel (2010) Confrontos com o Trabalho entre Jovens Avogados. As Novas Configurações da Inserção Profissional. Lisbon: Imprensa de Ciências Sociais.

chumbinho, João (2007) Julgados de Paz na Prática Processual. Lisbon: Quid Juris.

cunha, Manuela Ivone (2002) Entre o Bairro e a Prisão: Tráficos e Trajectos. Lisbon: Fim de Século.

DIAS, João Paulo (2004) O Mundo dos Magistrados. A evolução da organização e do auto-governo judiciário. Coimbra: Almedina.

DIAS, João Paulo (2012) O Ministério Público e o Acesso ao Direito e à Justiça: entre as competências legais e as práticas informais. Unpublished $\mathrm{PhD}$ dissertation, University of Coimbra.

DiAs, João Paulo (20I4) O Ministério Público no Acesso ao Direito e à Justiça. 'Porta de Entrada' para a Cidadania. Oporto: Afrontamento. 
DORes, António Pedro (2003) Prisões na Europa - Um debate que apenas começa / Prisons - Staking a Debate. Oeiras: Celta.

DORES, António Pedro (2009) Espírito de Submissão. Lisbon: Fundação Calouste Gulbenkian / Fundação para a Ciência e a Tecnologia.

DORes, António Pedro and PRETo, José (2013) Segredos das Prisões. Lisbon: Rui Costa Pinto.

DuARte, Madalena (20I I) Movimentos na Justiça - O Direito e o Movimento Ambientalista em Portugal. Coimbra: Edições Almedina.

DuARTe, Vera (2012) 'Contextos, discursos e percursos na delinquência juvenil feminina', Revista Configurações 9: I $2 \mathrm{I}-\mathrm{I} 33$.

FERnANDes, António Teixeira (I993) 'A sociologia e a modernidade', In Associação Portuguesa de Sociologia (ed.), Estruturas sociais e desenvolvimento (Actas do II Congresso Português de Sociologia), Vol. I. Lisbon: Fragmentos, 33-53.

FERReIRA, António Casimiro (2005) Trabalho Procura Justiça. Os Tribunais de Trabalho na Sociedade Portuguesa. Coimbra: Almedina.

FERREIRA, António Casimiro (20I I) 'A sociedade de austeridade: Poder, medo e direito do trabalho de exceção’, Revista Crítica de Ciências Sociais 95: I I9-136.

FERREIRA, António Casimiro and PEDROSo, João (2000) 'Entre o Passado e o Futuro : Contributos para um debate sobre a sociologia do direito em Portugal', Revista Crítica de Ciências Sociais 52/53: 333-362. FIRMIno, Sandra (20I I) 'Os Novos Arranjos Institucionais na Governança Pública: O Caso das Parcerias Público-Privadas. Estudo Comparativo entre o Sul e o Norte da Europa', Sociologia online 2, online: 〈http://revista.aps.pt/cms/files/artigos_pdf/ART4dc4of3ee8b26.pdf〉 (last accessed March 20I4). FRADE, Catarina (2003) 'A resolução alternativa de litígios e o acesso à justiça: A mediação do sobreendividamento', Revista Crítica de Ciências Sociais 65: 107-I 28.

FROIS, Catarina (20I I) Vigilância e Poder. Lisbon: Mundos Sociais.

garcia, Sofia Amaral, garoupa, Nuno and vilaça, Guilherme Vasconcelos (2008) A Justiça Cível em Portugal: Uma perspectiva quantitativa. Lisbon: Fundação Luso-Americana.

Gomes, Conceição (2003) O Tempo dos Tribunais: Um Estudo Sobre a Morosidade da Justiça. Coimbra: Coimbra Editora.

Gomes, Rui Machado (2002) 'A crise de legitimidade da organização escolar. Os dispositivos de legalização e a actualização dos mitos institucionais', Organização and Trabalho 28: 49-68.

gomes, Sílvia (2013) Criminalidade, Etnicidade e Desigualdades: Análise comparativa entre os grupos nacionais dos PALOP e Leste Europeu e o grupo étnico cigano. Unpublished PhD dissertation, Braga, Universidade do Minho.

GonçAlves, Maria Eduarda and Guibentif, Pierre (eds) (2008) Novos Territórios do Direito. Europeização, Globalização e Transformação da Regulação Jurídica. Estoril: Princípia.

gouveia, Mariana França, Garoupa, Nuno, and Magalhães, Pedro Coutinho (2013) Justiça económica em Portugal II - Factos e números. Lisbon: Fundação Francisco Manuel dos Santos (part of a set of several volumes).

Guedes, Armando Marques (2003) Pluralismo e Legitimação. A Edificação Jurídica Pós-Colonial de Angola. Coimbra: Almedina.

GUIBENTIF, Pierre (I997) La pratique du droit international et communautaire de la sécurité sociale - Etude de sociologie du droit de la coordination, à l'exemple du Portugal. Basel/Frankfurt-am-Main: Helbing and Lichtenhahn.

Guibentif, Pierre (2007) 'Les julgados de paz, une nouvelle justice de proximité au Portugal', Droit et Société 66: 33I-359.

GUIBENTIF, Pierre, GORJÃo, Vanda and CHETA, Rita (2002) Comunicação Social e Representações do Crime. Lisbon: CEJ.

hammerslev, Ole and rask madsen, Mikael (2014) 'The Return of Sociology in Danish Socio-legal Studies: A Survey of Recent Trends', International Journal of Law in Context Io(3): 397-4I5. 
HeRTOGH, Marc (20I2) 'Mind the (New) Gap: A Selective Survey of Current Law and Society Research in the Netherlands', International Journal of Law in Context 8: 137-I53.

hespanha, António Manuel (1986a) As Vésperas do Leviathan. Instituições e Poder Político. Portugal - Séc. XVII, Lisbon: Author; published (I994) Coimbra: Almedina.

HeSPANHA, António Manuel (I986b) 'As transformações revolucionárias e o discurso dos juristas', Revista Crítica de Ciências Sociais I8/19/20: 3I I-34I.

HeSPANHA, António Manuel (ed.) (2003) Feelings of Justice in the Chinese Community of Macao. Lisbon: ICS. hespanha, António Manuel (2007) O Caleidoscópio do Direito. O Direito e a Justiça nos Dias e no Mundo de

Hoje. Coimbra: Almedina.

ISRAËL, Liora (2013) 'Legalise It! The Rising Place of Law in French Sociology', International Journal of Law in Context 9(2): 262-278.

Jerónimo, Helena Mateus and neves, José (2012) 'O intelectual de retaguarda - Entrevista com Boaventura de Sousa Santos', Análise Social 47: 685-7 I I.

Leston-Bandeira, Cristina (2002) Da Legislação à Legitimação: o Papel do Parlamento Português. Lisbon: Imprensa de Ciências Sociais.

LOUREnço, Nelson and CARVAlHo, Maria João Leote (200I) 'Violência doméstica: Conceito e âmbito.

Tipos e espaços de violência', Themis II(3): 95-I22.

machado, Helena (2007) Moralizar Para Identificar. Cenários da Investigação Judicial da Paternidade. Oporto: Afrontamento.

MACHADO, Helena and COSTA, Susana (2012) 'Biolegalidade, imaginário forense e investigação criminal', Revista Crítica de Ciências Sociais 97: 6I-84.

machado, Helena and santos, Filipe (20II) Direito, Justiça e Média. Tópicos de Sociologia. Oporto: Afrontamento.

MACHURA, Stefan (2012) ‘German Sociology of Law: A Case of Path Dependency’, International Journal of Law in Context 8(4): 506-523.

MAgalhães, Pedro Coutinho (I995) 'Democratização e independência judicial em Portugal', Análise Social 30: 5I-90.

MagalHães, Pedro Coutinho and araújo, António de (I998) 'A justiça constitucional entre o direito e a política: o comportamento judicial no Tribunal Constitucional português', Análise Social 33: 7-53. MERTON, Robert K. (I 968) 'On Sociological Theories of the Middle Range', in Robert K. Merton, Social Theory and Social Structure. Glencoe: Free Press, 39-72.

miranda, Dilmar Santos de, marteau, Juan Félix, costa, Marcos Alberto, rocha, Maria Eduarda, and мотта, Rodrigo dos Santos (I996) 'As Ruínas Emergentes da Modernidade e a Pós-Modernidade

- Entrevista com Boaventura de Sousa Santos', Plural (Sociology Department of the University of São Paulo) 3: I35-I52.

monteiro, Rosa (20I2) 'A descriminalização do aborto em Portugal: Estado, movimentos de mulheres e partidos políticos’, Análise Social 47: 586-605.

mURAYAMA, Masayuki (2013) 'Kawashima and the Changing Focus on Japanese Legal Consciousness: A

Selective History of the Sociology of Law in Japan', International Journal of Law in Context 9(4): 565-589. Nolasco, Carlos (200I) 'As jogadas jurídicas do desporto ou o carácter pluralista do direito do

Desporto', Revista Crítica de Ciências Sociais 60: I4I-I69.

palacios CEREZAles, Diego (2003) 'Um caso de violência política : o Verão quente de I975’, Análise Social I65: II 27-II57.

PEDroso, João (20I I) Acesso ao Direito e à Justiça: Um direito fundamental em (des) construção. O caso do acesso ao direito e à justiça da família e das crianças. Unpublished $\mathrm{PhD}$ dissertation, University of Coimbra.

PEDroso, João, CASALeIro, Paula, and BRANCo, Patrícia (201 I) 'A odisseia da transformação do Direito da Família (1974-2010)', Sociologia, Revista da Faculdade de Letras da Universidade do Porto 2 I: 2 I 9-238. 
PEdroso, JoÃo, Trincão, Catarina and diAs, João Paulo (2003) Por Caminhos da(s) Reforma(s) da Justiça. Coimbra: Coimbra Editora.

PINTo, José Madureira (I993) 'A sociologia e as dinâmicas da modernidade', In Associação Portuguesa de Sociologia (ed.), Estruturas sociais e desenvolvimento (Actas do II Congresso Português de Sociologia), Vol. I. Lisbon: Fragmentos, 54-6r.

Rocha-cunha, Silvério da (2005) 'O trabalho de Sísifo do direito e da política no actual labirinto da sociedade mundial', Economia e Sociologia 80: I7 I-253.

ROSAS, Fernando, PIMENTEL, Irene Flunser, MADEIRA, João, FARINHA, Luís, and REZola, Maria Inácia (2009) Tribunais Políticos - Tribunais Militares Especiais e Tribunais Plenários durante a Ditadura e o Estado Novo. Lisbon: Círculo de Leitores.

Ruivo, Fernando (2000) O Estado Labiríntico: O Poder Relacional entre Poderes Local e Central em Portugal. Oporto: Afrontamento.

SANToS, Boaventura de Sousa (I974) Law against Law: Legal Reasoning in Pasargada Law. Cuernavaca (México): CIDOC (Centro Intercultural de Documentacion).

santos, Boaventura de Sousa (I984) A Justiça Popular em Cabo Verde (Estudo sociológico). Coimbra: Centro de Estudos Sociais (Research Report).

SANToS, Boaventura de Sousa (I985/r 990 ) 'Estado e Sociedade na Semiperiferia do Sistema Mundial: O caso português', Análise Social 2 I: 869-90i [republished in (I990a), I05-I50].

santos, Boaventura de Sousa (I986) 'Social Crisis and the State', In Kenneth Maxwell (ed.), Portugal in the 80's: Dilemmas of Democratic Consolidation. New York / Westport, CT / London: Greenwood Press, I67-I95.

santos, Boaventura de Sousa (I988) 'The Post-Modern Transition: Law and Politics'. Working Papers, Amherst: Amherst College, Department of Political Sciences.

santos, Boaventura de Sousa (I988/1994) 'O Social e o Político na Transição Pós-Moderna’, Revista de Comunicação e Linguagens 6/7: 25-48 [republished in Santos (1994) Pela Mão de Alice. O Social e 0 Político na Pós-Modernidade. Porto: Afrontamento, 69-10I].

SANTos, Boaventura de Sousa (I990a) O Estado e a Sociedade em Portugal (I974-I988). Porto: Afrontamento.

SAntos, Boaventura de Sousa (I990b) 'O Estado e o Direito na Transição Pós-Moderna : para um Novo Senso Comum sobre o Poder e o Direito', Revista Crítica de Ciências Sociais 30: I3-43.

santos, Boaventura de Sousa (1995) Toward a New Common Sense: Law, Science and Politics in the Paradigmatic Transition. New York / London: Routledge.

santos, Boaventura de Sousa (ed.) (200I) Globalização - Fatalidade ou Utopia? (vol. I of 8 of A Sociedade Portuguesa Perante os Desafios da Globalização). Oporto: Afrontamento.

santos, Boaventura de Sousa (2002) 'Can Law Be Emancipatory?' in B. S. Santos, Toward a New Legal Common Sense. London: Butterworth LexisNexis, 439-493.

santos, Boaventura de Sousa (ed.) (2003) Conflito e transformação social. Uma paisagem das justiças em Moçambique (2 vols). Oporto: Afrontamento.

Santos, Boaventura de Sousa, Bento, Maria, gonelha, Maldonado and costa, Alfredo Bruto da (I998) Uma visão solidária da Reforma da Segurança Social. Lisbon / Coimbra: União das Mutualidades Portuguesas / Centro de Estudos Sociais da Faculdade de Economia da Universidade de Coimbra. santos, Boaventura de Sousa and gomes, Conceição (I998) Macau - O pequeníssimo Dragão. Oporto: Afrontamento.

SAntos, Boaventura de Sousa, gomes, Conceição and DuARTE, Madalena (2009a) 'Tráfico sexual de mulheres: Representações sobre ilegalidade e vitimação', Revista Crítica de Ciências Sociais 87: 69-94.

santos, Boaventura de Sousa and Hespanha, Pedro (I987) 'O Estado, a Sociedade e as Políticas Sociais. O caso das políticas de saúde', Revista Crítica de Ciências Sociais 23: I3-72 [republished in (I990a), I93-257]. 
SANTos, Boaventura de Sousa, MARQues, Maria Manuel Leitãopedroso, João, and FerReIRA, Pedro Lopes (I996) Os tribunais nas sociedades contemporâneas : o caso português. Oporto / Coimbra / Lisbon: Afrontamento / CES / CEJ.

santos, Cecília MacDowell, santos, Ana Cristina, Duarte, Madalena, and Lima, Teresa Maneca (2009b) 'Homoparentalidade e desafios ao direito: O caso Silva Mouta na justiça portuguesa e no Tribunal Europeu de Direitos Humanos', Revista Crítica de Ciências Sociais 86: 43-68. santos, Susana (2012) O Movimento das Rádios Livres em Portugal: Formação de um Novo Espaço Social. Unpublished PhD dissertation, Lisbon, ISCTE-IUL. SILVA, Luisa Ferreira da (I99I) “'O direito de bater na mulher” - A violência interconjugal em Portugal', Análise Social 26: 385-397.

siLva, Susana (2007) 'Classificar e silenciar: vigilância e controle institucional sobre a prostituição feminina em Portugal', Análise Social 42: 789-810.

SILva, Susana and MACHADO, Helena (2010) 'A governação dos pacientes adequados no acesso à procriação medicalmente assistida em Portugal', Sociologia - Problemas e Práticas 62: 8I-96. sousA, Luís de (20II). Corrupção. Lisbon: Fundação Francisco Manuel dos Santos.

tavares, José A., maduro, Miguel Poiares, garoupa, Nuno and magalhães, Pedro (eds) (20i i) A Constituição Revista. Lisbon: Fundação Francisco Manuel dos Santos (e-book), online: 〈http:// ffms.pt/ebook/5/a-constituicao-revista> (last accessed June 2014).

Tinoco, Rui (2007) 'Notícias de uma investigação autobiográfica: o consumo de drogas como dilema moral', Sociologia - Problemas e Práticas 53: I59-I78.

vala, Jorge, Ramos, Alice and silva, Pedro (20I2) Confiança na Justiça. Paper presented at the Centro de Estudos Judiciários, November 2012 (publication in preparation).

vieira, Mónica Brito and silva, Filipe Carreira da (2010) O Momento Constituinte. Os Direitos Sociais na Constituição - Debates. Coimbra: Almedina. 